\title{
PENGARUH MODEL PEMBELAJARAN DISKUSI KELAS TIPE BEACH BALL TERHADAP HASIL BELAJAR PADA MATA PELAJARAN EKONOMI
}

\author{
Oleh: Titin Wulandari ${ }^{1}$, Zahruddin Hodsay ${ }^{2}$, Depi Pramika ${ }^{3}$ \\ titinwulandari1108@gmail.com ${ }^{1}$, zhodsay@gmail.com², \\ depi.neynda0506@gmail.com ${ }^{3}$ \\ (Program Studi Pendidikan Akuntansi, FKIP Universitas PGRI Palembang)
}

\begin{abstract}
Abstrak-Tujuan penelitian ini adalah untuk mengetahui pengaruh model pembelajaran diskusi kelas tipe beach ball terhadap hasil belajar siswa pada mata pelajaran ekonomi di SMA Negeri 7 Prabumulih. Metode penelitian yang digunakan adalah metode eksperimen atau eksperimental pendekatan penelitian kuantitatif. Hasil penelitian dengan menggunakan analisis regresi linier sederhana menunujukkan bahwa $t_{\text {hitung }} 5,277>t_{\text {tabel }}$ 1,999, sehingga berdasarkan kriteria $H_{o}$ ditolak dan $H_{a}$ diterima. Berarti ada pengaruh model pembelajaran diskusi kelas tipe beach ball terhadap hasil belajar siswa pada mata pelajaran ekonomi di SMA Negeri 7 Prabumulih Tahun Pelajaran 2019/2020. Dimana besar pengaruhnya adalah $31,4 \%$ sedangkan sisanya $(100-31,4)=68,6 \%$ dipengaruhi oleh faktor lain yang tidak dijelaskan dalam penelitian ini.
\end{abstract}

Kata Kunci: Model Pembelajaran, Diskusi Kelas Tipe Beach Ball, Hasil Belajar.

Abstract-The purpose of this study was to determine the effect of a beach ball type class discussion learning model on student learning outcomes in economic subjects at SMA Negeri 7 Prabumulih. The research method used is an experimental method or an experimental quantitative research approach. The results of the study using simple linear regression analysis showed that $t$ count 5.277> 1.999 table, so based on the criteria Ho was rejected and Ha was accepted. It means that there is an influence of the beach ball type class discussion learning model on student learning outcomes in economic subjects in SMA Negeri 7 Prabumulih 2019/2020 Academic Year. Where the effect is 31.4\% while the rest $(100-31.4)=68.6 \%$ is influenced by other factors not explained in this study

Keywords: Learning Model, Beach Ball Type Class Discussion, Learning Outcomes.

\section{PENDAHULUAN}

Di era modernisasi sekarang ini, kemajuan Ilmu Pengetahuan dan
Teknologi (IPTEK) sudah berkembang dengan sangat pesat. Dengan adanya perkembangan ini 
juga yang menuntut pemerintah di Indonesia agar mampu untuk terus memperbaiki kualitas generasi penerus bangsanya dengan mempersiapkan sumber daya manusia yang handal serta bersikap kritis, logis dan inovatif supaya dapat membentuk suatu bangsa yang mampu menghadapi berbagai tantangan global dunia dan demi keberlangsungan hidup dimasa depan. Salah satu upaya dari pemerintah untuk mewujudkan citacita bangsa yaitu dengan melalui dunia pendidikan.

Pendidikan adalah laksana eksperimen yang tidak pernah selesai sampai kapanpun, sepanjang ada kehidupan manusia di dunia ini. Dikatakan demikian, karena pendidikan merupakan bagian dari kebudayaan dan peradaban manusia yang berkembang. Dengan pendidikan diyakini dapat memaksimalkan potensi siswa sebagai calon sumber daya manusia (SDM) yang handal serta dapat bersikap kritis, logis, dan inovatif dalam menghadapi dan menyelesaikan setiap permasalah yang akan dihadapinya, melalui pendidikan di sekolah maka siswa mampu untuk mempersiapkan diri di masa yang akan datang untuk bisa bersaing secara luas dengan mengikuti proses belajar mengajar. Maka dalam proses pembelajaran yang dilaksanakan guru di dalam kelas harus menarik, menantang, dan menyenangkan agar siswa mampu mengembangkan potensi kognitif, afektif, dan psikomotorik sehingga hasil belajar siswa maksimal.

Keberhasilan proses belajar mengajar dapat dipengaruhi pada penentuan suatu model pembelajaran yang baik sehingga meningkatkan ketertarikan pada suatu jenis pembelajaran ekonomi yang diajarkan (Putri dkk, 2019:77-78). Untuk mencapai proses pembelajaran yang efektif, penggunaan model yang tepat mempunyai andil yang cukup besar. Kemampuan yang diharapkan dapat dimiliki anak didik ditentukan oleh kerelevansian penggunaan suatu model yang sesuai dengan tujuan pembelajaran. Tujuan pembelajaran akan dapat dicapai dengan penggunaan model yang tepat, sesuai dengan standar keberhasilan yang tercapai di dalam suatu tujuan. Model yang dapat dipergunakan dalam kegiatan belajar mengajar bermacam-macam.

Model mengajar merupakan suatu pola atau rencana yang dipakai guru dalam mengorganisasikan materi pelajaran, maupun kegiatan siswa dan dapat dijadikan petunjuk bagaimana guru mengajar di depan kelas (seperti alur yang diikutinya). "Penggunaan model mengajar tertentu akan menghasilkan pencapaian tujuan-tujuan yang telah diprogramkan maupun yang semula tidak diprogramkan (Mulyani dalam Suprihatiningrum, 2015:142)."

Pemilihan dan penggunaan model mengajar yang tepat dalam 
kegiatan pembelajaran diharapkan dapat mendorong siswa mau beraktifitas yang tepat secara nyata, seperti mengemukakan pendapat, mengajukan pertanyaan, memecahkan masalah, ketika proses belajar mengajar berlangsung baik secara perorangan maupun kelompok, sehingga potensi yang ada dalam diri siswa dapat berkembang sebagaimana mestinya. Maka digunakan model pembelajaran dengan cara berdiskusi di dalam kelas.

"Model pembelajaran diskusi kelas tipe Beach Ball, di mana guru memberi bola kepada salah seorang siswa untuk memulai diskusi dengan pengertian bahwa, hanya siswa yang memegang bola yang boleh berbicara. Siswa lain mengangkat tangan agar mendapat bola jika ingin mendapat giliran berbicara (Trianto, 2010:128)."

Pembelajaran ekonomi di hadapan para siswa kurang menarik, apabila disampaikan dengan model pembelajaran yang masih konvensional seperti ceramah dan tanya jawab. Karena peranan guru masih sangat dominan, dimana proses pembelajaran masih berpusat pada guru sehingga guru lebih aktif sebagai pemberi pengetahuan kepada peserta didik sementara peserta didik sangat pasif. Siswa hanya mendengarkan informasi yang diberikan oleh guru. Akibatnya siswa kurang termotivasi dalam proses pembelajaran. Untuk mengatasi hal tersebut salah satu alternatif digunakan model pembelajaran berupa diskusi kelas tipe beach ball untuk membuat siswa lebih aktif dalam mengikuti proses belajar mengajar.

Berdasarkan hasil observasi awal yang dilakukan di SMA Negeri 7 Prabumulih, peran guru disini masih sangat besar atau guru sebagai sumber pembelajaran dimana guru menyampaikan pembelajaran secara konvensinal yaitu bahan pelajaran sebagian besar disampaikan melalui ceramah dan hanya menggunakan proyektor serta laptop. Hasil belajar siswa sudah lumayan baik tetapi belum optimal. "Dikatakan belum optimal karena, pada saat proses pembelajaran beberapa siswa terlihat aktif dan mengikuti proses belajarmengajar dengan baik, tetapi pada saat menjawab soal latihan yang diberikan hasil dari jawaban siswa ada yang masih belum memahami, dilihat dari cara mereka memahami pelajaran yang diberikan.

"Menurut Pramika (2018:487)

Hasil belajar adalah suatu keberhasilan yang dimiliki peserta didik sebagai hasil pengalamannya sendiri dalam interaksi dengan lingkungannya melalui proses pelatihan, ketrampilan, ketekunan, pengetahuan yang ada dalam diri peserta didik."

Berdasarkan latar belakang yang telah diuraikan, yang menjadi rumusan masalah pada penelitian ini adalah Adakah Pengaruh Model 
Pembelajaran Diskusi Kelas Tipe Beach Ball Terhadap Hasil Belajar Siswa Pada Mata Pelajaran Ekonomi di SMA Negeri 7 Prabumulih Tahun Pelajaran 2019/2020?. Adapun tujuan dari penelitian ini adalah untuk mengetahui pengaruh model pembelajaran diskusi kelas tipe beach ball terhadap hasil belajar siswa pada mata pelajaran ekonomi di SMA Negeri 7 Prabumulih Tahun Pelajaran 2019/2020. Dari permasalahan yang dialami siswa seperti yang diuraikan di atas maka peneliti mengadakan peneliti dengan judul "Pengaruh Model Pembelajaran Diskusi Kelas Tipe Beach Ball Terhadap Hasil Belajar Siswa Pada Mata Pelajaran $\begin{array}{lllll}\text { Ekonomi di SMA Negeri } 7 & \end{array}$ Prabumulih Tahun Pelajaran 2019/2020".

\section{METODE PENELITIAN}

"Variabel Penelitian adalah gejala yang bervariasi, yang menjadi objek penelitian" (Arikunto, 2010:169). "Sedangkan Sugiyono (2011:61) mengatakan bahwa "Variabel penelitian adalah suatu atribut atau sifat atau nilai dari orang, obyek atau kegiatan yang mempunyai variasi tertentu yang ditetapkan oleh peneliti untuk dipelajari dan kemudian ditarik kesimpulannya". "Variabel dalam penelitian ini terdiri dari variabel bebas dan variabel terikat". a. Variabel bebas $(\mathrm{X})$ : Model Pembelajaran diskusi kelas tipe beach ball

b. Variabel terikat (Y) : Hasil belajar siswa

Adapun definisi operasional variabel dalam penelitian ini adalah sebagai berikut :

a. Model pembelajaran diskusi kelas tipe Beach Ball, yaitu model pembelajaran yang dapat menunjukkan kemampuan siswa dalam menyampaikan pemikiran mereka untuk memecahkan masalah dari materi pelajaran yang diberikan oleh guru di kelas, selain itu keaktifan siswa dalam menerima pelajaran lebih mudah untuk dipahami.

b. Hasil belajar yaitu hasil belajar siswa yang diperoleh setelah mengikuti pembelajaran dengan menggunakan model pembelajaran diskusi kelas tipe beach ball yang di peroleh melalui tes.

"Menurut Arikunto (2013:203) metode penelitian adalah cara yang digunakan oleh peneliti dalam mengumpulkan data penelitiannya". Metode yang digunakan dalam penelitian ini adalah metode eksperimen. "Menurut Sugiyono (2011:107) mengatakan bahwa "Metode Penelitian eksperimen dapat diartikan sebagai metode penelitian yang digunakan untuk mencari pengaruh perlakuan tertentu terhadap 
yang dinilai dalam kondisi yang terkendalikan."

"Menurut Sugiyono (2017:17) menyatakan bahwa "Populasi adalah wilayah generalisasi yang terdiri atas obyek/subyek yang mempunyai kualitas dan karakteristik tertentu yang ditetapkan oleh peneliti untuk dipelajari dan kemudian ditarik kesimpulannya". "Berdasarkan pengertian di atas, maka yang menjadi populasi dalam penelitian ini adalah seluruh siswa kelas XI IPS di SMA Negeri 7 Prabumulih Tahun Pelajaran 2019/2020 yang berjumlah 96 Siswa".

"Menurut Sugiyono (2016:118) sampel adalah bagian dari jumlah dan karakteristik yang dimiliki oleh populasi tersebut". Sedangkan "menurut Arikunto (2010:91) sampel adalah pemilihan sejumlah subjek yang mewakili populasi tersebut". "Sampel dalam penelitian ini adalah siswa kelas XI.IPS.1 yang berjumlah 31 siswa dan XI.IPS.2 sebanyak 32 siswa". "Teknik pengambilan sampel dalam penelitian ini adalah teknik Simple Random Sampling”. Dimana penentuan dilakukan secara acak agar setiap elemen atau anggota populasi memiliki kesempatan yang sama untuk terpilih menjadi sampel.

\section{HASIL DAN PEMBAHASAN}

"SMA Negeri 7 Prabumulih adalah sekolah yang berdiri tercatat pada tanggal 06 Juli 2009. Sekolah ini beralamatkan Jalan Lingkar Timur Kelurahan Muara Dua
Kecamatan Prabumulih Timur Kota Prabumulih, Provinsi Sumatera Selatan dengan Nomor Pokok Sekolah Nasional (NPSN) 10646553. SMA Negeri 7 Prabumulih didirikan berdasarkan SK Pendirian 2009-0409, serta SK Izin Operasional 153/KPTS/Disdik/2009". "Proses belajar mengajar berlangsung pada pagi sampai dengan sore hari dari hari Senin-Jum'at dengan menggunakan kurikulum 2013(k-13), dan telah memiliki akreditasi A. Sejak tanggal 15 September 2017 sampai dengan sekarang Kepala SMA Negeri 7 Prabumulih adalah Bapak Muhammad Aliyenah, S.Pd., M.Si”.

Dalam penelitian ini peneliti menggunakan 3 teknik dalam pengumpulan data yaitu, teknik dokumentasi, observasi, dan tes. "Teknik dokumentasi yang diambil berupa informasi mengenai data tentang jumlah siswa, populasi gambaran umum sekolah, jumlah guru dan pegawai di SMA Negeri 7 Prabumulih". "Teknik observasi digunakan untuk pengamatan keaktifan belajar siswa saat berlangsungnya proses pemmbelajaran". Sedangkan "teknik tes digunakan untuk mendapatkan data mengenai hasil belajar siswa setelah mengikuti proses belajar mengajar menggunakan model pembelajaran diskusi kelas tipe beach ball pada kelas XI.IPS.1 (eksperimen) dan model pembelajaran konvensional ceramah 
dan tanya jawab pada kelas XI.IPS.2 (kontrol)".

Penelitian ini dilakukan sebanyak 3 kali pertemuan, dengan dua kali pertemuan untuk proses belajar mengajar dan pertemuan ketiga diadakan tes dengan mengerjakan soal sebanyak 25 butir soal pilihan ganda untuk melihat hasil belajar siswa setelah mengikuti proses belajar mengajar.

Tabel 1. Distribusi Frekuensi Hasil Belajar Siswa Kelas Eksperimen

\begin{tabular}{|c|c|c|c|c|}
\hline No & Interval Penelitian & Frekuensi & Persentase & Keterangan \\
\hline 1 & $86-100$ & 6 & $19,35 \%$ & Baik Sekali \\
2 & $71-85$ & 20 & $64,52 \%$ & Baik \\
3 & $56-70$ & 5 & $16,13 \%$ & Cukup \\
4 & $41-55$ & 0 & $0 \%$ & Kurang \\
5 & $<40$ & 0 & $0 \%$ & Kurang Sekali \\
\hline \multicolumn{2}{|c|}{ Jumlah } & $\mathbf{3 1}$ & $\mathbf{1 0 0 \%}$ & \\
\hline
\end{tabular}

Sumber : Diambil dari Data Hasil Penelitian

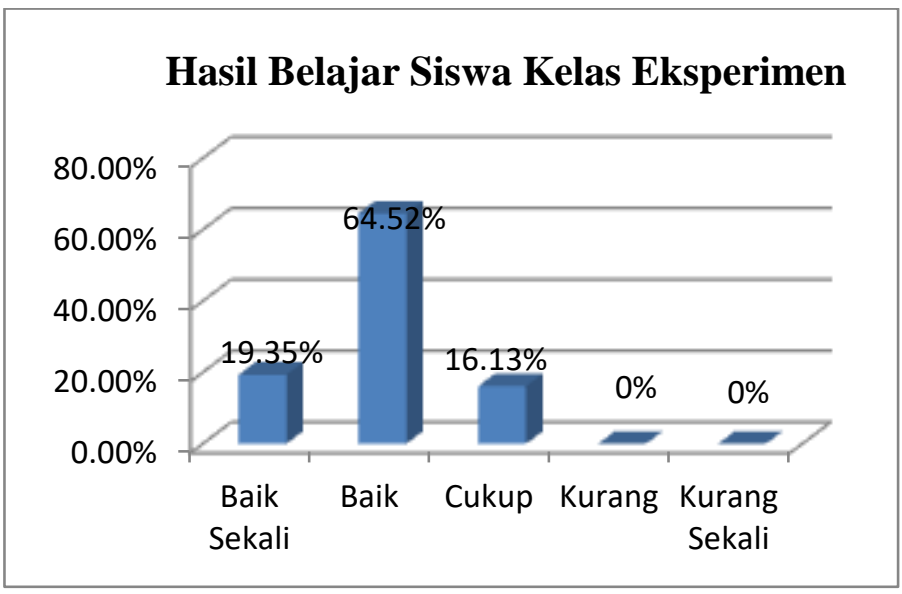

Gambar 1. Persentase Hasil Belajar Siswa Kelas Eksperimen

"Berdasarkan tabel hasil belajar siswa pada kelas eksperimen (XI.IPS.1) dengan jumlah 31 siswa, yang memperoleh nilai $86-100$ berjumlah 6 siswa dengan persentase 19,35\% pada kategori "Baik Sekali", siswa yang mendapat nilai 71-85 sebanyak 20 siswa dengan persentase $64,52 \%$ pada kategori "Baik", siswa yang mendapatkan nilai $56-70$ sebanyak 5 siswa dengan persentase $16,13 \%$ dengan kategori "Cukup", sedangkan tidak ada siswa yang mendapat nilai $41-55$ dan $<40 "$ " 
Tabel 2. Distribusi Frekuensi Hasil Belajar Siswa Kelas Kontrol

\begin{tabular}{|c|c|c|c|c|}
\hline No & Interval Penelitian & Frekuensi & Persentase & Keterangan \\
\hline 1 & $86-100$ & 0 & $0.00 \%$ & Baik Sekali \\
2 & $71-85$ & 14 & $43,75 \%$ & Baik \\
3 & $56-70$ & 16 & $50.00 \%$ & Cukup \\
4 & $41-55$ & 2 & $6,25 \%$ & Kurang \\
5 & $<40$ & 0 & $0.00 \%$ & Kurang Sekali \\
\hline \multicolumn{4}{r}{} \\
\hline
\end{tabular}

Sumber : Diambil dari Data Penelitian

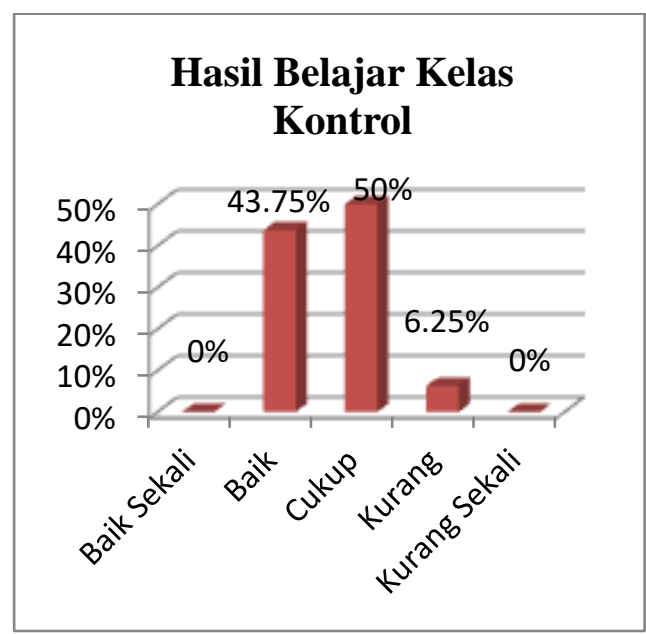

Gambar 2. Pesentase Hasil Belajar

Kelas Kontrol

"Berdasarkan hasil belajar siswa pada kelas kontrol (XI.IPS.2) dengan jumlah siswa 32, tidak ada siswa yang memperoleh nilai 86-100 pada kategori "Baik Sekali", siswa yang memperoleh nilai 71-85 sebanyak 14 siswa dengan persentase $43,75 \%$ pada kategori "Baik", sedangkan yang memperoleh nilai 56-70 sebanyak 16 siswa dengan persentase $50 \%$ pada kategori "Cukup", sebanyak 2 siswa yang memperoleh nilai 41-55 dengan persentase $6,25 \%$ pada kategori "Kurang", sedangkan tidak ada siswa yang memperoleh nilai $<40$ ".
"Analisis hasil observasi siswa dilihat dari proses belajar mengajar menggunakan model pembelajaran diskusi kelas tipe beach ball sebanyak 4 siswa dengan persentase $12,90 \%$ yang dikategorikan "Sangat Aktif”, selanjutnya ada 8 siswa dengan persentase $25,81 \%$ yang dikategorikan “Aktif", kemudian sebanyak 7 siswa dengan persentase 22,58\% dikategorikan "Cukup Aktif”. Selanjutnya ada 9 siswa dengan persentase $29,03 \%$ yang dikategorikan "Kurang Aktif" dan sebanyak 3 siswa dengan persentase 9,68\% yang dikategorikan "Sangat Kurang Aktif'. Rata-rata observasi yang diperoleh kelas eksperimen adalah sebesar 78,53 yang dikategorikan "Cukup".

Analisis hasil observasi siswa dilihat bahwa dalam proses belajar mengajar dengan menggunakan metode ceramah dan tanya jawab sebanyak 0 siswa dengan persentase $0 \%$ yang dapat dikategorikan "Sangat Aktif", selanjutanya ada 1 siswa degan persentase 3,13\% yang dikategorikan "Aktif", kemudian ada 10 siswa dengan persentase $31,25 \%$ 
yang dikategorikan "Cukup Aktif", sedangkan ada 13 siswa dengan persentase $\quad 40,63 \% \quad$ yang dikategorikan "Kurang Aktif". Selanjutnya, ada 8 siswa dengan persentase $25 \%$ yang dikategorikan "Sangat Kurang Aktif". Rata-rata observasi yang diperoleh kelas kontrol adalah sebesar 68,36 dengan kategori "Kurang Aktif".

Untuk melihat pengaruh model pembelajaran diskusi kelas tipe beach ball terhadap hasil belajar siswa pada mata pelajaran ekonomi di SMA Negeri 7 Prabumulih". Peneliti mengumpulkan data hasil tes yang diberikan pada pertemuan terakhir di kelas eksperimen dan kelas kontrol dengan materi pertumbuhan ekonomi dan pembangunan ekonomi. "Peneliti menggunakan rumus uji $\mathrm{t}$ dengan hasil perhitungan diperoleh harga $\mathrm{t}_{\text {hitung }}=5,277>$ dari $\mathrm{t}_{\text {tabel }}=1,999$ berarti tolak $\mathrm{H}_{\mathrm{o}}$ dan terima $\mathrm{H}_{\alpha}$ maka dapat dikatakan bahwa ada pengaruh dari model pembelajaran diskusi kelas tipe beach ball terhadap hasil belajar siswa yaitu sebesar $31,4 \%$ sedangkan sisanya sebesar $68,6 \%$ dipengaruhi oleh faktor lain". "Dari uraian di atas maka dapat diartikan bahwa penerapan model pembelajaran diskusi kelas tipe beach ball dapat meningkatkan hasil belajar siswa".

\section{KESIMPULAN}

Berdasarkan penelitian yang telah dilakukan, maka data observasi diketahui nilai rata-rata keaktifan siswa kelas XI.IPS.1 yang belajar menggunakan model pembelajaran diskusi kelas tipe beach ball dengan nilai 78,83. "Sedangkan pada kelas XI.IPS.2 yang belajar dengan menggunakan model pembelajaran konvensional dengan ceramah dan banya jawab memperoleh nilai 68,36".

"Berdasarkan hasil penelitian yang telah dilakukan oleh peneliti maka diketahui terdapat pengaruh pada hasil belajar siswa pada mata pelajaran ekonomi dengan menggunakan model pembelajaran diskusi kelas tipe beach ball tahun pelajaran 2019/2020. Hal ini terlihat dari hasil perhitungan uji $t$ yaitu $t_{\text {hitung }}$ $5,277>t_{\text {tabel }}=1,999$ maka $H_{0}$ ditolak dan $\mathrm{H}_{\mathrm{a}}$ diterima".

Berdasarkan hasil penelitian yang telah diuraikan tersebut maka peneliti menyarankan sebagai berikut:

a. Bagi Guru, khususnya guru mata pelajaran ekonomi agar dapat dijadikan sebagai salah satu alternatif model pembelajaran guru dalam kegiatan belajar mengajar sehingga diharapkan dapat meningkatkan hasil belajar siswa.

b. Bagi Sekolah, dapat meningkatkan kualitas kegiatan pembelajaran khususnya mata pelajaran ekonomi agar dapat mengembangkan model dan metode pembelajaran yang baik. 
c. Bagi Siswa, dengan menggunakan model pembelajaran diskusi kelas tipe beach ball yang diberikan dapat menciptakan situasi belajar yang menarik dan merangsang siswa untuk lebih aktif dalam belajar sehingga dapat meningkatkan hasil belajar yang baik.

d. Bagi peneliti selanjutnya hasil penelitian ini diharapkan dapat menambah wawasan pengetahuan, informasi, dan sumber bacaan bagi peneliti yang akan datang.

\section{DAFTAR PUSTAKA}

Arikunto, Suharsimi. (2014). Prosedur Penelitian Suatu Pendekatan Praktik. Jakarta: Rineka Cipta.

Pramika, Depi. (2018). Implementasi Metode Pemberian Tugas dan Resitasi Untuk Meningkatkan Aktivitas dan Hasil Belajar Mahasiswa Pada Mata Kuliah Matematika Ekonomi. Prosiding Seminar Nasional 21 Universitas PGRI Palembang. Pada tanggal 05 Mei 2018. (Online)

https://scholar.google.co.id/cita tions?user=wm_D2C0AAAAJ $\& \mathrm{hl}=\mathrm{id} \# \mathrm{~d}=\mathrm{gs}$ md cita$\mathrm{d} \& \mathrm{u}=\% 2$ Fcitations \%3Fview_o p\%3Dview_citation\%26hl\%3D id\%26user\%3Dwm_D2C0AA AAJ\%26citation_for_view\%3 Dwm_D2C0AAAAJ\%3Ad1gk VwhDpl0C\%26tzom\%3D-420. diakses tanggal 06 Agustus 2019.

Putri, Devi Nur Ahni Oktavia, Bukman Lian, dan Depi
Pramika. (2019). Pengaruh Model Pembelajaran Concept Attainment Terhadap Hasil Belajar Siswa Pada Mata Pelajaran Ekonomi di SMA Srijaya Negara Palembang. Jurnal Neraca: Jurnal Pendidikan dan Ilmu Ekonomi Akuntansi. Volume 3 No. 1 (2019) hal. 77-88. http://dx.doi.org/10.31851/nera ca.v3i1.3290.

Sugiyono, (2017). Metode Penelitian Pendidikan. Bandung: Alfabeta.

Suprihatiningrum, Jamil. (2015). Strategi Pembelajaran Teori \& Aplikasi. Yogyakarta: Ar-Ruzz Media.

Trianto, (2010). Mendesain Model Pembelajaran InovatifProgresif. Jakarta: Kencana. 